\title{
KSIĄDZ PROFESOR MAREK STAROWIEYSKI
}

Ks. prof. Marek Starowieyski, Prałat Jego Świątobliwości Jana Pawła II, urodził się w Krakowie, 25 stycznia 1937 roku, jako syn Mariana i Janiny z domu Rucz. Pochodzi z rodziny ziemiańskiej o bogatych tradycjach katolickich, społecznych, patriotycznych i literackich. Do jego przodków należy poeta i krytyk literacki Kazimierz Brodziński, sam jest praprawnukiem siostry wielkiego poety i pisarza Aleksandra Fredry, jego krewni to Zofia StarowieyskaMorstinowa („Ciocia Zosia” - jak o niej pisał) - pisarka i krytyk literacki, stryj bł. Stanisław Starowieyski, należący do grona 108 męczenników z czasów II wojny światowej, wybitny działacz Akcji Katolickiej, który wzorem swych rodziców a dziadków Księdza Jubilata w swym majątku w Łaszczowie pielęgnował jak najlepsze sąsiedzko-przyjacielskie stosunki dworu i wsi, oparte na wzajemnej współpracy i pomocy zarówno w sprawach materialnych jak i duchowych. W takiej atmosferze upływały pierwsze lata życia małego Marka.

Nie miał on jednak łatwego dzieciństwa i - jak sam wyznaje - praktycznie, nie miał też nigdy domu rodzinnego. Rodzina, po wyrzuceniu przez Niemców z majątku Bratkówka koło Krosna, mieszkała najpierw w Iwierzycach (k. Ropczyc), w dworze stryja Ludwika, a następnie w Siedliskach k. Szczekocin u wuja, Leona Komorowskiego, gdzie w 1945 r. zastała go reforma rolna, czyli wyrzucenie z majątku. W następnych latach Marek przebywał w wielu miejscowościach, gdzie uczęszczał do szkoły podstawowej (Nakło, Szczekociny), a następnie w Porąbce k. Kęt i w Zakopanem, gdzie wysłano go dla ratowania zdrowia. Do liceum ogólnokształcącego uczęszczał kolejno w Zakopanem, Krzeszowicach i w Sosnowcu, gdzie zdał maturę w liceum im Stanisława Staszica w roku 1954. Lata szkolne to jednak nie tylko nauka, ale także bardzo ciekawe spotkania, które wywierały na niego wpływ i go formowały. W Zakopanem często odwiedzał Ludwika Hieronima Morstina, gdzie w willi „Kozica” na Kasprusiach spotykał wielu ciekawych ludzi. Jeżdżąc przez Kraków, zatrzymywał się u Zofii Starowieyskiej-Morstinowej, gdzie częstymi gośćmi bywali Antoni Gołubiew, Jerzy Turowicz, Jerzy Zawieyski, Eugeniusz Kwiatkowski, Stefan Kisielewski i Władysław Tatarkiewicz. Bywał też często 
u matki chrzestnej Róży Łubieńskiej i u Marii Morstin-Górskiej, gdzie gromadzili się współpracownicy „Znaku” i często gościła Hanna Malewska czy Pia Górska. Te spotkania z intelektualnymi i literackimi elitami przygotowywały go i formowały także jego zainteresowania. Dodajmy, że w latach pięćdziesiątych pochodzenie z rodziny ziemiańskiej, czyli „obszarników” narażało na różne szykany władz szkolnych i bynajmniej nie ułatwiało dostania się na uniwersytet.

Po maturze, w 1954 r., rozpoczął studia filologii klasycznej na Uniwersytecie Warszawskim, które po roku przerwał i w 1955 r. wstąpił do Warszawskiego Seminarium Duchownego. Święcenia kapłańskie otrzymał w 1960 r. z rąk ks. kard. S. Wyszyńskiego. Przez trzy następne lata pracował jako wikariusz w Józefowie k. Otwocka, a kolejne dwa spędził jako rezydent w kaplicy w Nowej Wsi, w tejże parafii Józefów. Z tego rodzaju pracy, a więc z duszpasterstwa, nie zrezygnuje także w przyszłości, lecz będzie ją kontynuował jako kapelan u SS. Niepokalanek, najpierw w Warszawie, ul. Idzikowskiego (19741978), a potem w Burakowie (od 1985 r.); duszpastersko udzielał się także jako rezydent przy parafii Matki Bożej Loretańskiej w Warszawie (1978-1985).

W roku 1963 podjął przerwane studia filologii klasycznej na Uniwersytecie Warszawskim, które ukończył w 1966 r. ze stopniem mgr filologii klasycznej na podstawie pracy pisanej pod kierunkiem prof. dra K. Kumanieckiego Obraz literatury klasycznej pogańskiej w dziełach Izydora $z$ Sewilli, (opublikowana: „Meander” 29:1974, 357-367; 30:1975, 19-35). Promotora pracy do dziś wspomina jako swojego wielkiego mistrza.

W latach 1965-1968 wykładał język łaciński i grecki w Metropolitalnym Seminarium w Warszawie a równocześnie zdobył stopień licencjata teologii w Akademickim Studium Teologii Katolickiej w Warszawie na podstawie

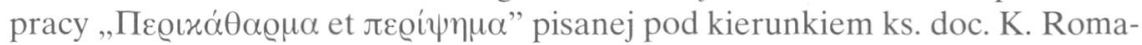

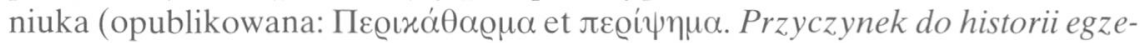
gezy patrystycznej, „Eos” 78:1990, 281-295).

W latach 1968-1971 studiował na Papieskim Uniwersytecie Gregoriańskim w Rzymie, na którym otrzymał tytuł doktora teologii ze specjalizacją w teologii historycznej na podstawie pracy Maria-Eva in traditione Antiochena, Alexandrina et Palaestinensi saeculo V (Roma, Marianum 1972), pisanej pod kierownictwem O. Prof. I. Ortiz de Urbina SJ z Papieskiego Instytutu Orientalnego w Rzymie.

W latach 1971-1974 pracował w Kongregacji ds. Wychowania Katolickiego w Watykanie. Ta praca niezupełnie mieściła się w jego planach: podjął ją na prośbę ks. kard. Stefana Wyszyńskiego, ale sam wspomina, że prośba ta znaczyła tyle, co rozkaz. Mimo tego i wbrew oczekiwaniom, także to miejsce pracy okazało się miejscem spotkania z Kościołem i z jego wybitnymi osobistościami: kard. G.M. Garrone, i z arcybiskupem (późniejszym kardynałem) J. Schröfferem. Tam też spotykał o. prof. C. Martiniego - późniejszego arcybiskupa 
Mediolanu, prof. G. Lazzattiego - rektora Uniwersytetu Mediolańskiego, o. M. Krąpca i kard. K. Wojtyłę - odpowiedzialnego za sprawy nauki katolickiej w Polsce oraz wielu innych ludzi nauki z całego świata. W czasie pobytu w Rzymie uczęszczał też na wykłady na Papieskim Instytucie Archeologii Chrześcijańskiej oraz odbył szereg podróży do krajów związanych z kulturą wczesnochrześcijańską lub posiadających muzea związane z tą kulturą (Włochy, Francja, Anglia, Belgia, Holandia, Niemcy, Palestyna, Syria, Turcja, Tunezja, Grecja).

W 1974 r. powrócił do Polski i na nowo podjął pracę w Metropolitalnym Seminarium Duchownym w Warszawie oraz w miejscowym Papieskim Wydziale Teologicznym, kolejno jako adiunkt, docent i profesor nadzwyczajny patrologii. W 1985 r. zrobił habilitację na Papieskim Wydziale Teologii w Krakowie w zakresie patrologii, a w 1990 r. został mianowany profesorem Papieskiego Wydziału Teologicznego w Warszawie.

Jednocześnie, przez długie lata pracował także w innych Seminariach Duchownych: w latach 1975-1994 wykładał patrologię w Wyższym Seminarium Duchownym Stowarzyszenia Apostolstwa Katolickiego w Ołtarzewie, w latach 1994-1998 i w 2005 r. w Wyższym Seminarium Duchownym w Łowiczu, a w roku akademickim 1999/2000 w Wyższym Seminarium Duchownym w Siedlcach.

W 1992 r. podjął pracę w Instytucie Filologii Klasycznej Uniwersytetu Warszawskiego, a 1 września 1995 otrzymał nominację na stanowisko profesora nadzwyczajnego tegoż Uniwersytetu. W 2000 roku został profesorem zwyczajnym w Instytucie Filologii Klasycznej UW. Jednocześnie, od 1998 r. wykładał gościnnie dwa lata na Papieskim Uniwersytecie Gregoriańskim w Rzymie oraz Instytucie Patrystycznym „Augustinianum” (Papieski Uniwersytet Laterański) w Rzymie, gdzie dotąd prowadzi zajęcia przez jeden semestr w roku.

Jest autorem kilkunastu książek, w przygotowaniu kilkudziesięciu uczestniczył opracowując je merytorycznie i redakcyjnie, pisząc wstępy, komentarze, wybierając teksty, lub przygotowując przekłady. Napisał kilkaset artykułów naukowych i publicystycznych. Przygotował dużą liczbę tłumaczeń tekstów patrystycznych na język polski. Brał udział w ponad stu audycjach w TV Polskiej, Telewizji Niepokalanów, w Polskim Radiu i w Radiu Watykańskim.

Jest badaczem wszechstronnym i zajmuje się wieloma dziedzinami. Zasadnicze kierunki badań naukowych Jubilata to: starożytna literatura monastyczna grecka i łacińska, poezja wczesnochrześcijańska łacińska, grecka i orientalna, apokryfy chrześcijańskie Nowego Testamentu i w ogóle kultura wczesnochrześcijańska. Trudno w tej krótkiej biografii pokusić się na jakiekolwiek, skrótowe scharakteryzowanie tego dorobku naukowego. Sam Czytelnik będzie mógł się z nim zapoznać studiując zamieszczoną niżej jego bibliografię. Niemniej trudne jest również przedstawienie Jego działalności organizacyjnej i wydawniczej. Ksiądz Profesor był i jest aktywnym członkiem wielu komisji 
i rad, oraz polskich i międzynarodowych redakcji. W latach 1978-1996 był członkiem Komisji do Spraw Nauki Katolickiej oraz Rady Naukowej Episkopatu Polskiego. Aktualnie od 1977 r. jest współzałożycielem i członkiem Sekcji Patrystycznej przy Komisji Nauki Episkopatu Polski, członkiem Komitetu Nauk o Kulturze Antycznej i Komisji Bizantynologicznej PAN, delegatem z Polski w Societé Internationale des Études Patristiques (AIEP), członkiem Association pour l'Étude de la Littérature Apocryphe Chrétienne (AELAC, Paryż, Genewa), sekcji polskiej Comitée International de l'Histoire Ecclésiastique Comparée (CIHEC), oraz Polskiego Towarzystwa Filologicznego (PTF). Jest też aktualnie redaktorem „Warszawskich Studiów Teologicznych” (wydawanych przez Papieski Wydział Teologiczny, Sekcja św. Jana Chrzciciela, w Warszawie), członkiem komitetu redakcyjnego rocznika „Apocrypha” (Paryż), czasopisma „Scripta Theologica” (Pamplona), i miesięcznika „Meander” (Warszawa). Jest ponadto redaktorem takich serii patrystycznych, jak: „Ojcowie Żywi” („Znak”, WAM, 17 tomów), „Źródła Monastyczne” (Tyniec Kraków, 43 tomy), do 1998 r. był także redaktorem „Biblioteki [i Małej Biblioteki] Ojców Kościoła” (Wyd. M, Kraków, 10 + 3 tomy). W 1994 r. zorganizował w Tyńcu międzynarodowe spotkanie na temat duchowości monastycznej i przygotował wydanie dwóch tomów jego aktów (por. Bibliografia).

Bierze nadal udział, zazwyczaj wygłaszając referaty, w międzynarodowych kongresach i spotkaniach. Wymienić tu można chociażby gwoli przykładu: kongresy patrystyczne w Oksfordzie, Comitée International de l'Histoire Ecclésiastique comparée, spotkania poświęcone Grzegorzowi z Nyssy (Mainz, St. Andrew's), spotkania patrystyczne w „Salesianum” i „Augustinianum” w Rzymie, międzynarodowe spotkania na temat apokryfów chrześcijańskich w Lozannie - Genewie i Dole, spotkania teologiczne w Pamplonie, w Paryżu (Ecole Pratique des Hautes Études, Instytut Katolicki), w Chantilly i w Lyonie; nie można oczywiście zapomnieć o spotkaniach i kongresach polskich oraz o zaangażowaniu w działalność Sekcji Patrystycznej przy Komisji Nauk Episkopatu Polski.

Obok monumentalnego dorobku naukowego, wielkim dziełem Jubilata jest zorganizowany przez niego przy Wyższym Seminarium Warszawskim zakład naukowy wyspecjalizowany w kulturze wczesnochrześcijańskiej z biblioteką liczącą ponad 20000 woluminów (plus około sześćdziesięciu czasopism). Dziś jest to nieoceniony warsztat pracy patrologa otwarty dla studentów i badaczy z całej Polski, powstały dzięki znajomościom i kontaktom Twórcy, budowanym i pielęgnowanym przez lata studiów, wyjazdów, kongresów i spotkań. Jest to jednocześnie owoc żmudnej pracy poszukiwacza, godzin, dni i tygodni spędzanych w składach dubletów w podziemiach zachodnich bibliotek uniwersyteckich w poszukiwaniu książki patrystycznej. Zakład wraz z biblioteką powstał mimo długiego czasu komunistycznego odizolowania Polski, mimo uciążliwości związanych nie tylko z pozyskaniem, ale także z wwozem publikacji do Polski, 
rewizji i szykan polskich, czeskich i NRD-owskich, a w końcu i austriackich celników (sam Jubilat wspomina, że zwłaszcza te pisane innym alfabetem greckim czy którymś z orientalnych - budziły ich szczególny niepokój). Zakład ten bardzo wrósł w warszawskie środowisko patrystyczne, że dziś trudno wyobrazić sobie bez niego pracę patrologa w Stolicy.

W ciągu swej długoletniej pracy dydaktycznej wypromował dwóch doktorów, kilkudziesięciu magistrów i licencjatów, oraz przygotował kilkanaście recenzji prac doktorskich i habilitacyjnych. Jest doskonałym dydaktykiem. Jego zajęcia to dla studentów nie tyle wykłady, ile uczta, w czasie której chłoną zarówno przebogatą wiedzę, jak i stykają się z szeroko pojętą kulturą, z dziedziny literatury (nie tylko wczesnochrześcijańskiej), architektury, sztuk plastycznych i muzyki. To także zajęcia, w których wykładowca staje się pedagogiem i mistrzem, a ich przedłużeniem są spotkania przy okazji kolejnej wielkiej pasji Księdza Profesora, jaką jest turystyka górska (jest Przodownikiem GOT [G. Świętokrzyskie, Beskidy]) i nizinna, krajoznawstwo (od 1952 r. jest członkiem PTTK). Zorganizował i poprowadził ponad sto obozów wędrownych czy dłuższych wycieczek.

Jubilat wymienia z wdzięcznością Profesorów, którzy wywarli wielki wpływ na Jego formację i których uważa za swoich mistrzów. Są to: na Uniwersytecie Warszawskim wybitny klasyk prof. Kazimierz Kumaniecki oraz prof. Lidia Winniczuk; w Seminarium Duchownym i Warszawskim Wydziale Teologicznym: ks. prof. Wincenty Kwiatkowski (apologeta), ks. prof. Janusz Tarnowski (katecheta), ks. prof. Czesław Jakubiec (biblista) i ks. prof. Bogusław Inlender (moralista); na Papieskim Uniwersytecie Gregoriańskim w Rzymie: mistrz jego pracy doktorskiej, O. Ignazio Ortiz de Urbina SJ (syriolog), O. Eduard des Places SJ (klasyk) i Antonio Orbe SJ (teolog). To długa lista, lecz wiemy, że Jubilat czerpał z ich bogactwa i nie tylko go nie zaprzepaścił, ale też zebrawszy skarby mądrości swych poprzedników, na wzór wielkich Mistrzów starożytności, którym poświęcił swoje życie, przekazuje je wytrwale i umiejętnie swym uczniom. Z pewnością więc retorycznie tylko można postawić pytanie jak długa jest lista tych, którzy właśnie Czcigodnego Jubilata już dziś umieszczają w gronie swoich najwybitniejszych Mistrzów. 